\title{
POSTMODERNISME DAN IDEOLOGI BUDAYA NASIONAL
}

\author{
Agustini Buchari \\ MAN MODEL MANADO
}

\begin{abstract}
Abstrak
Ciri utama postmodernisme dan postrukturalisme adalah penolakan terhadap adanya satu pusat, narasi besar, dan gerak sejarah yang monolinier. Postmodernisme dan postrukturalisme mensubversi uniformitas, homogenitas, dan totalisasi dengan memberikan intensitas terhadap perbedaan, multikulturalisme, pluralisme, bahkan relativisme. Postmodernisme sering dikacaukan dengan postrukturalisme. Postmodernisme adalah abad, zaman, era, generasi, dan periode, atau paham dan aliran dengan berbagai persoalannya, sedangkan postrukturalisme adalah tradisi intelektual, teori-teori yang digunakan untuk memecahkan masalah-masalah yang berkaitan dengan postmodernisme itu sendiri.
\end{abstract}

Kata Kunci : Postmodernisme, budaya, nasional 


\section{A. Pendahuluan}

Postmodernisme telah menjadi sebuah istilah yang tersebar di manamana. Beberapa surat kabar besar di berbagai Negara menyusun seri tulisan mengenai postmodernisme. Acara-acara siaran televisi membahas persoalanpersoalan yang muncul dalam postmodernisme. Hampir semua topik dalam jurnal-jurnal periodik yang berkaitan dengan hal-hal yang berbau budaya pernah menerbitkn edisi khusus mengenai postmodernisme. Hampir semua topik dalam jurnal-jurnal periodik yang berkaitan dengan hal-hal yang berbau budaya pernah menerbitkan edisi khusus mengenai postmodernisme.

Postmodernisme sering dikacaukan dengan postrukturalisme (Ratna, 2009). Postmoderisme adalah abad, zaman era, generasi dan periode, atau paham dan aliran dengan berbagai persoalannya, sedangkan postrukturalisme adalah tradisi intelektual, teori-teori yang digunakan untuk memecahkan masalah-masalah yang berkaitan dengan postmodernisme itu sendiri. Secara etimologis historis postmodernisme lahir sesudah modernisme, postrukturalis setelah strukturalis.

Ciri utama postmodernisme dan postrukturalisme adalah penolkan terhadap adanya satu pusat, narasi besar, dan gerak sejarah yang monolinier. Postmodernisme dan postrukturalisme mensubversi uniformitas, homogenitas, dan totalisasi dengan memberikan intensitas terhadap perbedaan, multikulturalisme, pluralisme, bahkan relativisme.

Istilah postmodern sudah digunakan di Barat tahun 1870-an, oleh seniman Inggris John Watkins Chapman (Ratna, 2009). Istilah ini muncul kembali sekitar tahun 1930-an melalui Federico de Onis sebagai salah satu reaksi terhadap kelemahan modernisme. Postmodern menjadi populer tahun 1970- 
an, yaitu dalam bidang arsitektur, tari, drama, seni lukis, film, dan musik (Hardiman, 2009). Melalui seni gaya, istilah ini menjadi populer, dan persis dalam bidang-bidang itulah istilah postodern dipertentangkan dengan istilah modern. Seni yang disebut modern itu menjaga kemurniannya dari kecenderugan untuk jatuh menjadi hiburan populer yang besifat masal. Seni mdern mengikuti standar-standar formal dan berusaha mempertahankan kebudayaan luhur dari masa silam. Berlawanan dengan itu, seni yang disebut postmodern justru mendukung kebudayaan massa. Seni ini mengandung pemberontakan radikal terhadap ide formalisme dan seni hiburan populer itu. Batas-batas kebudayaan elite dan keudayaan massa yang dijaga ketat dalam seni modern justru dihancurkan dalam seni postmodern.

Kelompok akar budaya yang paling terkemuka, Kajian Budaya Inggris, yang berhubungan dengan Pusat Kajian Budaya Kontemporer Universitas Birmingham. Asal tradisi ini biasanya diusut dari Richart Hoggart dan Raymond Williams pada tahun 1950-an yang menguji kelas pekerja inggris setelah perang dunia II (dalam Littlejohn dan Fost, 2008). Saat itu nama yang paling berhubungan dengan pergerakan ini adalah Stuart Hall. Walaupun dipengaruhi oleh pemikiran Marxis, semua pakar ini mengambil jalur yang agak berbeda dalam pemikiran mereka tentang komukiasi yang menekan.

Tradisi kajian budaya dengan jelas berorienasi reformis. Semua pakar ingin melihat perubahan dalam masyarakat, dan mereka memandang ilmu pengetahuan mereka sebagai sebuah alat perjuangan budaya sosialis. Mereka mempercayai bahwa perubahan akan terjadi pada dua cara, yaitu: 1) dengan mengidentifikasi kontradiksi dalam masyarakat, resolusi yang akan membawa dampak positif, sebagai lawan dari menindas; dan 2) dengan memberikan interpretasi yang akan membantu manusia memahami dominasi dan pembuahan yang di inginkan. 
Kajian komunikasi masa adalah inti dari karya ini karena media di anggap sebagai alat yang sangat kuat bagi ideologi dominan. Sebagai tambahan, mmedia memiliki potensi dalam membangkitkan kesadaran populassi tentang isu kelas, kekuasaan dan dominasi.

Postmodernisme dikatakan menguraikan lahirnya suatu tatanan sosial tempat arti penting maupun kekuatan media masa dan budaya populer yang berarti kesemuanya itu mengatur dan membentuk segala macam hubungan sosial (Setrinati,1995). Gagasannya adalah bahwa tanda-tanda budaya populer maupun citra media semakin banyak mendominasi realitas, diri kita, dan dunia di sekitar kita.

Salah satu implikasi penting adalah tampilan permukaan dan gaya menjadi lebih penting di dalam dunia posmo dan pada gilirannya menuntut semacam "ideologi perancang". Sebagaimana di kemukakan oleh Harvey (dalam Setrinati, 1995). "Cintraan mendominasi narasi" argumennya adalah kita semakin sering mengkonsumsi citra maupun tanda itu sendiri dan bukannya "manfaatnya" atau nilai-nilai lebih dalam yang mungkin di simbolisasikan. Kita mengkonsumsi citra dan tanda karena semuanya itu memang citra dan tanda, dan mengabaikan pertanyaan tentang nilai dan kegunaan.

\section{B. Postmodernisme dan budaya populer}

\section{Arsitektur}

Postmodernisme dalam arsitektur menolak bangunan-bangunan dan arsitektur di ciptakan menjadi baru sesuai dengan prinsip-prinsip rasional dan ilmiah. Dalam arsitektur postmodern, tonggaknya adalah bangunanbangunan yang sangat banyak ornamen, di rancang sungguh-sungguh, di kontekstualkan dan diberi warna cerah, sebuah penekanan pada fiksionalitas dan sifat main-main, serta penggabungan gaya yang di ambil dari berbagai periode sejarah yang berbeda. 
Arsitektur postmodern mengerjakan dan mengubah gaya bangunan menjadi perayaan gaya dan permukaan, memanfaatkan arsitektur untuk membuat lelucon tentang ruang yang di bangun ( misalnya Grandfather Clock karya Philip Johnson di New York dan Piazza Italia karya Charles Moore di New Orleans). Arsitektur postmodern juga mengerjakan dan mengubah gaya bangunan di sesuaikan dengan konteks tempat bangunan itu berada dan memadukan dengan gaya klasik ( misalnya, gaya Romawi atau Yunani Kuno) dengan gaya lokal ( tanda-tanda dan ikon-ikon budaya populer).

\section{Film}

Argumen-argumen postmodernis memperhatikan masalah visual dan film-film yang menekankan pada gaya, tontonan, efek, dan citraan khusus, dengan mengorbankan isi, karaker, substansi, narasi, dan kritik sosial. Contohnya film Dick Tracey (1990), Indian Jones (1981), dan serial Back to Future (1985). Film- flm tersebut tampaknya menekankan tontonan dan aksi melalui penggunaan teknik-teknik yang canggih dan rangkaian usaha tak berbelas kasihan, dan bukannya kompleksitas maupun nuansa jalinan alur dan pengembangan karakter. Kadang- kadang di katakan bahwa tuntutan naratif realisme klasik semakin di abaikan oleh film postmodern.

\section{Televisi dan periklanan}

Acara televisi lebih banyak mempertahankan konfensi stilistika dan petualangan sinema daripada acara rutinitas televisi yang tenang, akrab dan lebih realistis.

Iklan televisi di gunakan untuk mengetahui apakah memungkinkan untuk memberi contoh lebih jauh tentang lahirnya postmodernisme dalam budaya populer kontemporer. Argumen yang disampaikan disini adalah bahwa dahulu iklan biasanya menyampaikan kepada audien betapa bernilai dan bermanfaatnya sebuah produk. Kini iklan lebih sedikit 
menyampaikan soal produk secara langsung, dan lebih mengambil rujukan-rujukan dari budaya populer maupun dengan secara sadar memperjelas statusnya sebagai iklan. Argumen ini mengakui bahwa iklan selalu di libatkan dalam menjual barang kepada orang-orang, tapi menunjukan bahwa ciri-ciri tersebut memberi ciri khas pada unsur-unsur postmodernisme yang dapat di jumpai dalam iklan masa kini.

\section{Musik Pop}

Sejarah mutakhir musik pop dalm postmodernisme di tandai oleh suatu kecenderungan kearah perpaduan secara eksplisit terhadap berbagai macam aliran dan genre musik secara langsung dan sadar. Perpaduan ini berkisar antara perpaduan ulang secara langsung dari lagu-lagu yang sudah di rekam dari era yang sama atau berbeda pada rekaman yang sama, sampai mengambil dan mencicipi musik, bunyi dan instrumen yang berbeda dengan tujuan menciptakan identitas subkultural yang baru

Inovasi-inovasi musikal dengan kolase, pengutipan, dan perpaduan aliran yang secara musikal dan historis maiz berbeda, dengan penggabungan acak dan selektif diantara berbagai bidang macam musik dan gaya, dengan penolakan pemilahan antara musik senang-senang atau pop dengan serangan terhadap musik rock yang disusun secara artistik.

\section{Postmodernisme dan ideologi budaya di Indonesia}

Para pakar kajian budaya membicarakan budaya dalam dua cara. Definisi pertama adalah ide dasar sebuah masyarakat atau kelompok tentram, ideologinya, atau cara kolektifnya pada suatu kelompok yang memahami perasaannya. Definisi kedua adalah praktik atau keseluruhan cara hidup dari kelompok, apa yang individu lakukan secara materi dari hari ke hari (Littlejohn dan fost,2008). Dua pengertian budaya tersebut tidak benar-benar terpisah karena ideologi dari sebuah kelompok di produksi dan di reproduksi dalam praktiknya. Pada kenyataannya, perhatian umum dari para ahli teori adalah hubungan antara tindakan dari institusi masyarakat, seperti halnya 
media dan budaya. Ide dan praktik selalu terjadi bersama dalam sebuah konteks historis.

Sebagai contoh, manusia menonton televisi setiap hari, membuat mereka bagian dari televisi. Seluruh industru televisi adalah sebuah budaya produksi karena itu adalah sarana untuk menciptakan perselisihan, produksi ulang, dan mengubah budaya. Praktik konkrit melibatkan produksi dan mengonsumsi televisi adalah mekanisme penting dalam pembentukan ideologi.

Mulai awal tahun 1980-an kelompok-kelompok teater Jakarta kontemporer seperti teater sae dan teater kubur, dan para penulis, seperti Afrizal Malna, Nirwan Dewanto, dan Seno Gumira Ajidarma, mulai mengeksplorasi praktik-praktik budaya postmodern dalam gaya penulisan dan pagelaran mereka. Selanjutnya kecenderungan ini tersebar luas di kalangan generasi baru pekerja teater di ibukota Indonesia ini. Awal 1990-an praktikpraktik dan gaya postmodern telah mulai tampil di tempat lain, baik di teater maupun di dalam fiksi dan kritik para penulis mudah yang semakin bertambah jumlahnya. Karya sastra yang di hasilkan ini tumbuh atas ketidakpasan kelas menengah terhada politik orde baru (orba) akhir yang semakin meningkatnya komersialisasi budaya indonesia, posmodernisme indonesia ini merupakan usaha baru perlawanan terhadap menifestasi sosial dan budaya yang telah meresap pada rezim otoriter Soeharto, dan sekaligus merupakan respons terhadap kondisi hidup dan produksi artistik yang baru, baik menolak maupun yang menyambut dengan baik.

Penolakan para pendukung postmodernisme terhadap ideologi orba mengenai bangsa dan identitas pribadi merupakan kaitan sentral antara para pendukung postmodernisme di Indonesia dengan pengertian postkolonialitas. Jika ideologi orba mengenai kontrol dan ketertiban di anggap konsisten dengan kepribadian atau filsafat Indonesia (filsafat pancasila) yang tradisional, maka dapat di nyatakan bahwa para pendukung pstmodernisme 
Indonesia berkepedulian untuk menemukan strategi-strategi untuk menggorogoti nativisme yang di bangun oleh negara (Littlejohn dan fost, 2008).

Posmodernisme Indonesia di masa orba di antaranya memiliki kecenderungan untuk memimpikan adanya sistem nilai-nilai universal atau bentuk komunitas sebagai alternatif visi masyarakat yang lebih khas yang melatarbelakangi dasar-dasar ideologis negara Indonesia. Sejumlah pekerja budaya secara langsung menantang baik modernisme maupun pengertian negara dan bangsa sebagai kerangka yang sesuai untuk mengukur dan mengkategorisasikan kegiatan budaya, atau untuk menjelaskan susunan identitas individual kontemporer.

Posmodernsme Indonesia di produksi dalam iklim umum oposisi yang semakin meningkat terhadap orba. Pemerintah orba telah mencoba melakukan 1) kontrol yang semkin efektif terhadap media dan ranah-ranah produksi budaya yang lain, 2) mewajibkan pelatihan ideologi resmi untuk berbagai kategori pegawai negeri dan mengumumkan asas tunggal pancasila untuk semua organisasi sosial dan 3) menguasai dan membentuk kembali bentukbentuk budaya dan praktik "tradisional" untuk mendorong programnya demi pembangunan dan erkembangan ekonomi bangsa. (Littlejohn dan fost, 2008).

Debat Indonesia mengenai postmodernisme sejak akhir tahun 1980-an dan awal tahun 1990-an menurut Heryanto (Bodden 2008) ada kaitannya dengan meningkatnya kesejahteraan dan keyakinan sosial kelas menengah Indonesia, dan bertepatan dengan pentingnya diskusi- diskusi mengenai keterbukaan, hak-hak asasi manusia demokratisasi.

Tulisan Heryanto tahun 1994 dalam majalah budaya yang baru, Kalam di nyatakan bahwa pembangunan Indonesia sejenis dengan modernisme yang mempercayai kemajuan linear, kebenaran ilmiah mutlak, kemajuan rekayasa sosial dan pembentukan sistem ilmu pengetahuan dan produksi yang formal. 
Kemudian ia mendaftar sejumlah aspek 'negatif' masyarakat orba yang menurutnya adalah akibat mengikuti visi modernis barat.

Post modernisme menurut Heryanto bermanfaat di Indonesia untuk secara radikal menyengsikan berbagai kepastian yang sudah lama didambakan masyarakat. Posmodernisme bisa membantu membuka kemungkinankemungkinan yang sebelumnya di anggap tabu, irasional, atau mustahil. Salah satu perbandingan Heryanto adalah tekanan orba pada kontrol, ketertiban dan hierarki terpusat yang di tegaskan sebagai bagian dari kepribadian Indonesia yang hakiki.

Tantangan yang lebih khusus terhadap ideologi- ideologi budaya dominan orba di temukan dalam pidato kunci Nirwan Dewanto dalam kongres kebudayaan nasional akhir tahun 1991 (Bodden, 2008) Dewanto menyinggung cerita besar tentang modernisme Indonesia yang disamakan dengan hak istimewa kepada negara bangsa kesatuan sebagai kerangka acuan akhir dan logis untuk produksi budaya. Bagian yang hakiki dari perkembangan cerita nasional tentang budaya menurutnya adalah asumsi yang untuk pertama kali di kemukakan di masa Sutan Takdir Alisjahbana dan polemik kebudayaan bahwa standar untuk mengukur semua budaya adalah standar budaya tinggi di tingkat nasional, bukan akktivitas budaya lokal dan kerakyatan. Cerita ini kemudian di perluas oleh kultus universal terhadap genius seni yang mengagungkan pencipta perorangan modern yang melebihi dan menentang tradisi.

Postmodernisme dalam teater di Indonesia diprakarsai oleh Teater sae di awal tahun 1990-an (Bodden, 2008). Penulis naskah drama Afrizal Malna dan direktur Boedu S. Otong menyampaikan gagasan-gagasan yang rumit mengenai peralatan, bahkan kebutuhan untuk jenis teater yang telah mereka ciptakan. Malna menegaskan bahwa teater tidak dapat lagi di jelaskan lewat diri para tokoh individunya. Baginya, individu diera globalisasi, industrialisasi, standardisasi, budaya orba dan sifat lembaga-lembaga sosial 
yang semakin monolit berada dalam krisis. Dalam konteks ini, terutama karena di mediasi oleh televisi, surat kabar, radio, dan film, hubunganhubungan baru dengan masyarakat terbuka akibat memecah- mecah kepribadian individu, baik dengan membesarkan maupun dengan menggemboskan 'diri' itu.

Posmodernisme dalam novel Indonesia tampak dalam karya Ajidarma tahun 1996. Ajidarma menampilkan suatu dunia dimana keindahan cepat menguap, cinta dan hubungan antar manusia hanya sekilas dan menyakitkan, sedangkan penyiksaan dan pembunuhan brutal tak ada hubungannya dengan keadilan. Ada beberapa tempat didalam teks dimana narator menyesalkan berlalunya matahari terbenam yang indah keemasan (saat menjelang datangnya malam yang sepi dan sangat menakutkan).

\section{Simpulan}

Postmodernisme sering dikacaukan dengan postrukturalisme. Postmodernisme adalah abad, zaman, era, generasi dan periode, atau paham dan aliran dengan berbagai persoalannya, sedangkan postrukturalisme adalah tradisi intelektual, teori-teori yang di gunakan untuk memecahkan masalahmasalah yang berkaitan dengan postmodernisme itu sendiri.

Postmodernisme dikatakan menguraikan lahirnya suatu tatanan sosial tempat arti penting maupun kekuatan media massa dan budaya populer yang berarti kesemuanya itu mengatur dan membentuk segala macam hubungan sosial. Gagasannya adalah bahwa tanda-tanda budaya populer maupun citra media semakin banyak mendominasi realitas, diri kita, dan dunia disekitar kita.

Postmodernisme dimulai awal tahun 1980-an, kelompok-kelompok teater Jakarta kontemporer seperti teater Sae dan teater kubur, dan para penulis, seperti Malna, Dewanto, dan Ajidarma, mulai mengeksplorasi praktik-praktik budaya postmodern dalam gaya penulisan dan pagelaran mereka. Awal 1990an praktik-praktik dan gaya postmodern telah mulai tampil di tempat lain, 
baik di teater maupun dalam fiksi dan kritik para penulis muda yang semakin bertambah jumlahnya. Karya sastra yang di hasilkan ini tumbuh atas ketidakpuasan kelas menengah terhadap politik orde baru 


\section{Daftar Pustaka}

Bodden, Michael. 2008. Satuan-Satuan Kecil dan Improvisasi Tak Nyaman Menjelang Akhir Orde Baru: Demokratisasi, Postmodernisme, dan Postkolonialitas. Terjemahan oleh Koeslah Soebagyo Tor dan Monique Soesman. Sastra Indonesia Modern; Kritik Kolonial. Jakarta: Yayasan Obor Indonesia.

Hardiman, F. B. 2009. Menuju Masyarakat Komunikatif: Ilmu, Masyarakat, Politik, dan Postmodernisme menurut Jurgen Habermas. Yogyakarta: Kanisius

Littlejohn , S. W. Dan Foss, K, A. 2009. Teori Komunikasi. Terjemahan oleh Mohammad Yusuf Hamdan. Jakarta: Salemba Humanika

Ratna, N. K. 2009. Stilistika: Kajian Puitika Bahasa, Sastra, dan Budaya. Yogyakarta: Pustaka Pelajar

Srinati, D. 2009. Popular Culture. Terjemahan oleh Abdul Muchid. Yogyakarta: ARRuz Media 